DOI 10.37882/2223-2982.2021.10-2.19

\title{
ОРГАНИЗАЦИЯ СТАТИСТИЧЕСКИХ ОБСЛЕДОВАНИЙ ПЕРЕСЕЛЕНЦЕВ В АЛТАЙСКОМ ОКРУГЕ В КОНЦЕ ХІХ - НАЧАЛЕ ХХ ВЕКА (ПО МАТЕРИАЛАМ ОБЩЕСТВА ЛЮБИТЕЛЕЙ ИССЛЕДОВАНИЯ АЛТАЯ)
}

\section{ORGANIZATION OF STATISTICAL SURVEYS OF IMMIGRANTS IN THE ALTAI DISTRICT AT THE END OF THE 19TH - BEGINNING OF THE 20TH CENTURIES (BASED ON THE MATERIALS OF THE SOCIETY OF FANS OF ALTAI RESEARCH)}

V.Skopa

Summary: The article focuses on the elaboration of statistical census forms. The population of the resettlement settlement did not represent anything homogeneous. It broke up into a number of isolated groups that were characterized by the most diverse features. In addition to the question of the degree of economic well-being, it was established where the migrants came from and from which class elements the migrant mass itself was composed. For a detailed study of this issue, tables were developed in which the settlers were divided both by the provinces from which they left, and by class groups. The total number of summary tables was more than five hundred, where the main issues related to the situation of migrants in the points of settlement in the Altai District were revealed.

Keywords: history, settlers, Altai district, statistics, researchers of Altai.

\author{
Скопа Виталий Александрович \\ Д.и.н., профессор, Алтайский государственный \\ педагогический университет, г. Барнаул \\ sverhtitan@rambler.ru
}

Аннотация: В статье внимание уделено проработке переписных форм статистического учета. Население переселенческого поселка не представляло собой ничего однородного. Оно распадалась на ряд обособленных групп, которые характеризовались самыми разнообразными чертами. Помимо вопроса о степени экономического благосостояния было установлено откуда переселенцы прибыли и из каких сословных элементов слагалась сама переселенческая масса. Для детального изучения данного вопроса были разработаны таблицы, в которых переселенцы разбивались как по губерниям, из которых вышли, так и по сословным группам. Общее количество сводных таблиц составляло более пятисот, где раскрывались главнейшие вопросы, касающиеся положения переселенцев в пунктах водворения в Алтайском округе.

Ключевые слова: история, переселенцы, Алтайский округ, статистика, исследователи Алтая.
$\mathrm{H}$ ачиная со второй половины XIX века активизировался процесс развития капиталистических отношений в Российской империи. Модернизационные процессы, вызванные Великими реформами Александра II, охватили все стороны жизни и деятельности. Отмена крепостного права рушила устои многовековой истории. Усиливающиеся миграционные процессы затрагивали отдаленные территории, вовлекая местное население в пучину активного движения и желание вжиться В изменяющиеся траектории развития. В данном процессе в стороне не остался и Алтайский округ, некогда являвшийся мощнейшим центром добычи и выплавки серебра [9]. Округ относился к ведомственным территориальным образованиям, входившим в состав более крупных административных единиц, на которые делился сибирский край в соответствии с общегосударственным районированием [13].

Начиная с конца XIX века поток переселенцев в Ал- тайский округ был очень сильным и фактически неуправляемым. Активные миграционные процессы оказывали существенное влияние на экономику, социальную сферу региона, а также заставляли действующую власть предпринимать какие-либо меры в части системного расселения переселенцев и их благоустройства $[2,11]$. С этой целью на Общество любителей исследования Алтая была возложена задача осуществить исследование переселенцев по накопленным материалам в период 1890-1894 годов [3]. Ответственным за данную работу был определен С. П. Швецов, имеющий солидный опыт в части статистического дела и формирования переписных листов.

Весь материал, который предполагалось переработать был разделен на общее описание переселенческого поселка и детальное описание каждого переселенческого двора, то есть хозяйственную единицу, которая уже не подлежала дальнейшему дроблению [1, 4]. Исходя 
из этого была определена методика обработки данных. В своем конечно виде, полученный материал, как отмечал С.П. Швецов, должен был с группировок так, чтобы «каждый кто желал им воспользоваться имел возможность проверить выводы и заключения» [5, л. 78]. Так же Швецов отмечал, что каждому «переселенческому поселку должно быть дано полное и сжатое писание, способное охарактеризовать поселок во всех его основных чертах, а затем по каждому же поселку должны быть составлены статистические таблицы, которые в полной мере рисовали экономическое положение населения» [5, л. 113]. Данный переработанный материал по всем поселкам должен был составить первую часть исследования, в которой заключалось только фактическая сторона дела: статистические сводки, группировки по объектам обследования, переписные и опросные листы [7]. Аналитическая разработка этого фактически уже систематизированного материала со всеми следующими из него выводами и заключениями должна была составить вторую часть исследования [7].

По имеющимся материалам, население переселенческого поселка, даже самого позднего образования, не представляла собой ничего однородного. Оно распадалась на ряд более или мене обособленных групп, которые характеризовались самыми разнообразными чертами [10]. Выявить это дробление переселенческой массы ее размер и значение - это было одной из важнейших задач поселенных таблиц. С этой целью все населения каждого поселка было разбито на четыре основные группы: первая - переселенцы причисленный к поселку; вторая группа - переселенцы не причисленные [12]. Стоит отметить, что сюда входили все переселенцы, которые явились на Алтай извне Алтайского округа. Но кроме них здесь были еще переселенцы старожилы, под которыми подразумевали перешедших с места на место в пределах Алтайского округа, это была третья самостоятельная группа - переселенцы старожилы; и старожилы - четвертая группа [7, с. 15-17]. Главное значение, как это видно из самого перечисления групп, сохранялось за первыми двумя, так как именно в их в интересах было предпринято само исследование. Две последние подгруппы в целом могли быть рассмотрены как единое целое, две первые расчленены по признакам, которые являлись наиболее характерными для понимания степени экономического благосостояния каждый из них. Одним из таких определяющих признаков было время, в течение которого переселенцы жили в селении, а именно, чем дольше жил человек на одном месте, тем предполагалось, что положение его является более устойчивым и определившимся. Поэтому все переселенцы первой группы, уже причисленные, разбивались в таблицах на пять подгрупп по времени водворения, а именно: первая - живущие в поселках до одного года; вторая - до трех лет; третья - до пяти лет; четвертая - до десяти лет; пятая - свыше десяти лет. Так же деление принято было и для второй группы, то есть переселенцев не причислен- ных, но их число подгрупп было уменьшено, так как исключена была четвертая подгруппа - водворившиеся до десяти лет и, для последний приняты все переселенцы, живущие в поселке более пяти лет [11, с. 254]. В целом, данная градация позволяла всецело охватывать население с учетом его миграции и обоснования на территории расселения.

Кроме продолжительности проживания в данном поселке на степень экономического благосостояния переселенцев, как было отмечено в переписной форме, огромное влияние оказывало и другое обстоятельство, а именно: «бродили переселенцы и сколько времени до водворения были в данном поселке» [11]. Факт предварительного перемещения переселенцев одинаковое значение имел и для причисленных и для не причисленных переселенцев поскольку и там, и там были приняты одни и те же деления на группы: первая группа - переселенцы, вовсе не бродившие до водворения в поселке; вторая - бродившие с места на место до трех лет; третья - бродившие более трех лет [12]. Данные дробления позволяли проследить степень большей или меньшей устойчивости переселенческой массы и влияние этой устойчивости на ее экономическое благосостояние.

Не причисленные переселенцы в своей массе резко различались между собой по тем условиям, на основании которых они жили в поселке, так как условия сильно влияли на весь склад жизни переселенцев. С этой целью все не причисленные переселенцы были разбиты на три группы: первая - проживающие в поселках по паспортам, полученным на родине; вторая - проживающие по свидетельствам главного управления Алтайского округа; третья - проживающие по увольнительным свидетельствам с родины, то есть ушедших оттуда совсем, но еще не успевших причислиться в округе [11]. Разбив таким образом население на ряд групп и подгрупп представленная таблица рассматривала каждую из заявленный групп порознь и в тоже время - вместе, что давало объективные показатели по всем объектам обследования.

Отдельное внимание в деле обследования переселенцев было уделено вопросу, касающегося наемного труда в переселенческом хозяйстве, поскольку, как отмечал С.П. Швецов он «имел важное значения для уяснения всей постановки переселенческого дела и положения переселенцев на Алтае» [8]. С этой целью были отдельно составлены графы учета, половина которых имела ввиду продажу переселенцами своего труда, а другая - покупку труда, то есть наем рабочих для своего хозяйства [12].

В рассмотрении данного вопроса С.П. Швецовым было указано, что «в целях настоящего исследования чрезвычайно важно было не только уяснение положения переселенцев в данный момент, в рассматриваемом случае значение формы наемного труда, но и прошедшая история переселенцев, - в вопросе о наемным 
труде - значение этого последнего в предшествовавшие годы жизни переселенцев в новых местах водворения» [7]. Исходя из этого часть таблиц были посвящены истории экономического развития населения и этому было отведено 16 граф. Далее таблицы заключали данные о жилищах, какими владели и пользовались переселенцы; количестве земли отведенной в пользование поселком, снимаемый и сдаваемой переселенцами в аренду; о размерах и значении земледельческого промысла, о способах обработки, инвентаре, урожайности; о значении размера скотоводства; плодоводстве; пчеловодстве; обрабатывающей промышленности, ремесла и торговли; о денежных платежах и повинностях [12]. Такими представленными отделами исчерпывалось общее описание экономического положения переселенческих поселков, их населения в момент исследования. Стоит отметить, что отдельно были включены вопросы, касающиеся грамотности населения; причин не причисления переселенцев; несчастные случаи, постигшие в первые года водворения переселенцев; причины падения переселенческих хозяйств; стоимость водворения в поселок для причисленных и проживания в нем для не причисленных переселенцев [11].

Все сводные таблицы в общей сложности заключили 527 граф и раскрывали главнейшие вопросы, касающиеся положение переселенцев в пунктах водворения в Алтайском округе.

Помимо вопроса о степени экономического благосостояния, достигаемого переселенцами в Алтайском округе, чрезвычайно важно было установить откуда переселенцы прибыли сюда и из каких сословных элементов слагалась сама переселенческая масса. С этой целью были составлены особые дополнительные таблицы, в которых переселенцы разбивались, во-первых - по губерниям, из которых вышли; во-вторых - по сословным группам, а именно: шести разрядам крестьян, мещане, солдаты и другие сословия [11].

В каждую из этих таблиц, которые были разделены на экономическо-групповую и сословно-порайонную, заносились данные по отдельному селению отдельно, а затем уже производилось сводка поселенных данных в таблицы по районам, а после уже в общий итог по всему Алтайскому округу.

Для распределения переселенческих поселков по типичным районам были приняты за основу следующие признаки: «находится ли поселок в степной местности или гористой, а затем - в лесной или безлесной». В соответствии с этим были выделены 4 района: «степнойбезлистный; степной-лесной; горный-безлесный; горный-лесной» [11]. Для каждого поселка в таблицах была отметка к какому он административному округу и волости принадлежит. Это нужно было для того, чтобы, если возникала необходимость, перепроверить сводки по волостям или селениям с целью уточнения информации или ее корректировки. Стоит заметить, что данная практика корректировок являлась не единичной, а носила системный характер, что в целом способствовало более объективному представлению материала.

Из выше изложенного видно, насколько обширную и сложную работу предстояло сделать на основе собранного экспедицией статистического материала, а в последствии дать заключение по общим показателям.

Одной из проблем с которой пришлось столкнуться членам общества при организации обследования, была кадровая проблема. Сильное замедление в подсчетах произошло из-за того, что в Барнауле весьма трудно было подыскать счетчиков, которые быстро и удовлетворительно работали [9]. Данная сложность была свойственна и для действующей системы статистического учета. Труд этот требовал не только большого количества рабочих рук для самого подсчета, но еще и наблюдения, и проверки. Для решения данной проблемы совет общества любителей исследования Алтая пригласил А.А. Селина, принявшего на себя обязанности за 60 руб. в месяц не только подыскать в Барнауле нужное количество счетчиков, но и следить за их работами и производить проверку всего подсчета. Но как показало время, в данной должности А.А. Силен проработал всего около двух месяцев, после чего он перешел на службу в главное управление Алтайского округа и от проверки отказался. Всеми проверочные работами безвозмездно занялась Мария Швецова, супруга Сергея Порфирьевича [7].

К началу работы нужное количество счетчиков все же было набрано. Их плата была установлена с подворной карточки по 3 коп., а к осени повысилась до 5 коп. За эту плату счетчик обязан был произвести подсчеты по всем графам и группам таблиц $[7,8]$. В случае обнаружения ошибок счетчик должен их исправить и сдать в переписной стол чистые формы. Объем работ, касающийся подведения итогов по селению, вычисление процентных отношений, средних чисел также лежал на счетчиках за ту же сдельную плату.

Решение кадровой повлекло за собой необходимость задуматься членам общества о финансировании сего мероприятия. Помимо проведения работ по исследованию переселенческих поселков, как отмечалось в отчете «совет общества был озабочен и изысканием денежных средств, которые позволяли бы не только продолжать разработку материала, но и в последствии издать весь труд» [7].

В этом трудном деле незаменимую услугу оказал совету общества действительный его член В.Т. Зимин предложивший принять на себя труд по изысканию денежных средств для окончания работ. При его посредничестве в общество поступили следующий суммы: от Ю.И. Базано- 
вой - 500 руб., А.Г. Ккаменского - 100 руб., А.Е. Владимирова, М.М. Зензинова, П.И. Похолкова, Н.М. Чукмалдина, К.М. Сибирякова - по 50 руб. Из этого видно, что материальную сторону предпринятого действия можно считать решенным.

Таким образом, организационные начала, предпринятые обществом любителей исследования Алтая в процессе изучения переселенческих поселков в Алтайском округе, позволили комплексно и всесторонне подойти к данному мероприятию, и в итоге получить адекватный и верифицированный материал. Сформированные сведения на основе разработанных переписных таблиц объективно отражали картину переселенческого дела в регионе и во многом являлись инструментарием в управленческих начинаниях по данному вопросу. Заложенные объекты статистического учета в переписные формы по изучению переселенцев в дальнейшем будут отражены в текущем статистическом учете отраслевого характера в работах статистического бюро Алтайского округа. Системно накапливаемые статистические сведения о регионе приобретали статус делопроизводственных документов.

1. Гозулов А.И. Очерки истории отечественной статистики. М., 1972. 274 с.

2. Государственная статистика России М., 1997. 289 с.

3. Демшин Я. Одно из старейших: Общество любителей исследования Алтая // Алтайская правда. 1959. 1 ноября. С. 4.

4. Кауфман А.А. Статистическая наука в России. Теория и методология. 18061917 гг. Историко-критический очерк. М., 1922. 412 с.

5. Краевое государственное казенное учреждение «Государственный архив Алтайского края» Ф. 4. Оп. 1. Д. 48.

6. Краевое государственное казенное учреждение «Государственный архив Алтайского края» Ф. 4. Оп. 1. Д. 33.

7. Отчет Совета общества Любителей исследования Алтая за 1894 год. Барнаул, 1895. 43 с.

8. Отчет Совета Общества любителей исследования Алтая за 1895 год. Томск, 1896. 54 с.

9. Скопа В.А. Кадровая проблема статистических служб в Алтайском округе конца XIX-началаXX в. // Актуальные проблемы археологии, истории и культуры. Материалы региональной научно-практической конференции. Новосибирск, 2005. С. 149-151.

10. Хозяйственно-статистическое описание крестьянских волостей Алтайского округа. СПб., 1885. 469 с.

11. Швецов С.П. Материалы по исследованию мест водворения переселенцев в Алтайском округе: результаты статистического исследования в 1894 году. Описание переселенческих поселков. Барнаул, 1899. Т. 4.560 c.

12. Швецов С.П. Переселенцы на Алтае: результаты статистического исследования мест водворения переселенцев в Алтайском округе в 1894 г. Барнаул, 1899. Т. 4. Вып. 1-2.83 с.

13. Соболева Т.Н. Управление горнозаводским хозяйством Кабинета на Алтае в XVIII- перв. пол. XIX в. // Алтайский сборник. Вып. XIV. Барнаул, 1991.

(c) Скопа Виталий Александрович (). sverhtitan@rambler.ru

Журнал «Современная наука: актуальные проблемы теории и практики» 